\title{
Analisis Kebutuhan Sumber Belajar Matakuliah Anatomi Fisiologi Manusia Berdasarkan Model Pengembangan Analyze Design Develop Implement Evaluation
}

\author{
Dita Purwinda Anggrella ${ }^{1}$, Sri Endah Indriwati ${ }^{1}$, Sri Rahayu Lestari ${ }^{1}$ \\ ${ }^{1}$ Pendidikan Biologi-Universitas Negeri Malang
}

\section{INFO ARTIKEL}

Riwayat Artikel:

Diterima: 06-07-2018

Disetujui: 11-08-2020

\author{
Kata kunci: \\ needs analysis; \\ anatomy of human physiology; \\ ADDIE development model; \\ analisis kebutuhan; \\ anatomi fisiologi manusia; \\ model pengembangan ADDIE
}

\begin{abstract}
ABSTRAK
Abstract: The purpose of this study was to analyze the learning resources used during lectures at IKIP Budi Utomo Malang in the Human Physiology Anatomy course. This type of research is exploratory research. The population in this study were all Biology students of IKIP Budi Utomo, and the study sample was used by 40 students who have taken courses in human physiology anatomy. Data collection techniques through observation, interviews and questionnaires. Data obtained was analyzed descriptively qualitatively. The results showed that the main learning resources used in the form of textbooks and internet pages, the learning environment only occurs in the classroom due to limited laboratories, lack of facilities and infrastructure to support learning activities and practicum, as well as learning methods that less trigger students to be active such as presentation discussions, questions, and answers.
\end{abstract}

\begin{abstract}
Abstrak: Tujuan penelitian ini untuk menganalisis sumber belajar yang digunakan selama kegiatan perkuliahan di IKIP Budi Utomo Malang pada matakuliah Anatomi Fisiologi Manusia. Jenis penelitian ini adalah penelitian eksploratif. Populasi dalam penelitian ini adalah seluruh mahasiswa Biologi IKIP Budi Utomo, dan sampel penelitian yang digunakan 40 mahasiswa yang telah menempuh matakuliah Anatomi Fisiologi Manusia. Teknik pengumpulan data melalui observasi, wawancara, dan pengisian angket. Data yang diperoreh dianalisis secara deskriptif kualitatif. Hasil penelitian menunjukkan bahwa sumber belajar utama yang digunakan berupa buku teks dan laman internet. Lingkungan belajar hanya terjadi di dalam kelas karena terbatasnya laboratorium, kurangnya sarana sarana dan prasarana utuk menunjang kegiatan belajar dan praktikum, serta metode pembelajaran yang kurang memicu mahasiswa untuk bersifat aktif, seperti diskusi presentasi, tanya jawab, dan ceramah.
\end{abstract}

\section{Alamat Korespondensi:}

Dita Purwinda Anggrella

Pendidikan Biologi

Universitas Negeri Malang

Jalan Semarang 5 Malang

E-mail: Ditaanggrella11@gmail.com

Tantangan pembelajaran pada abad 21 menuntut pemberdayaan keterampilan abad 21 bagi lembaga pendidikan agar menghasilkan lulusan yang berkompetensi dan dapat bersaing di era globalisasi. Institut Keguruan dan Ilmu Pendidikan (IKIP) Budi Utomo Malang merupakan salah satu lembaga pendidikan swasta yang berbasis kependidikan dan keguruan di kota Malang yang menaungi program studi Pendidikan Biologi yang memiliki tujuan menghasilkan lulusan yang berkompetensi di bidang pendidikan dan pengetahuan Biologi. Salah satu matakuliah wajib yang ditempuh mahasiswa Prodi Pendidikan Biologi IKIP Budi Utomo adalah Anatomi Fisiologi Manusia (Anfisman) untuk mencapai kualitas kelulusan yang sesuai dengan kompetensi yang diharapkan.Tercapainya kompetensi tersebut dan diberdayakannya keterampilan abad 21 perlu didukung dengan sumber belajar untuk menunjang proses pembelajaran. Purwanto (2003) mengungkapkan sumber belajar merupakan segala sesuatu yang dapat menyampaikan pesan sehingga tujuan belajar dapat tercapai.

Sumber belajar menurut AECT dalam Daryanto (2010) dapat dikelompokkan sebagai berikut (1) pesan (message) merupakan informasi yang disampaikan dalam bentuk ide, fakta, makna, nilai, dan data, (2) manusia (people) sebagai peyampai, pengolah, dan penyimpan informasi, misalnya adalah pendidik atau teman sebaya (3) bahan (materials) berupa sesuatu yang mendukung dalam penyampaian informasi, missal buku, video, (4) alat (device) yang berperan sebagai penyampai pesan dalam bahan, (5) metode/teknik (technique) merupakan prosedur dalam menyampaiakn pesan, contohnya ceramah, diskusi, (6) lingkungan (setting) yang merupakan situasi sekitar dimana pesan akan disampaikan. Macam-macam dari sumber 
belajar tersebut akan membentuk suatu sistem sehingga saling ketergantungan dengan komponen pengajaran yang lainnya. Sumber belajar yang perlu digunakan dalam matakuliah harus disesuaikan dengan kebutuhan sehingga perlu dilakukan analisis kebutuhan untuk mengetahui kebutuhan mahasiswa dalam proses pembelajaran pada mahasiswa program studi Pendidikan Biologi. Anfisman merupakan salah satu matakuliah wajib yang ditempuh mahasiswa pada semester IV dengan jumlah Sistem Kredit Semester sebanyak 3. Pemilihan matakuliah Anfisman dalam penelitian ini karena matakuliah ini berhubungan dengan kehidupan sehari-hari dan tergolong abstrak sehingga perlu untuk dilakukan analisis lebih dalam untuk membantu mahasiswa memperoleh pengetahuan dari sumber belajar yang tersedia sehingga capaian pembelajaran yang dirumuskan dalam tujuan pembelajaran dapat tercapai.

Tahapan dalam proses analisis kebutuhan di IKIP Budi Utomo ini merujuk pada model pengembangan Analyze Design Develop Implement Evaluation (ADDIE) tahapan Analyze (Branch, 2009). Hasil dari analisis kebutuhan kemudian akan digunakan sebagai pijakan dalam menentukan sumber belajar yang sesuai dengan kebutuhan mahasiswa pada matakuliah anfisman untuk menunjang keterampilan abad 21. Model pengembangan ADDIE dipilih karena terstruktur jelas, setiap tahapan terdapat evaluasi sehingga dapat diketahui kekurangan dari setiap tahapannya, dan bersifat fleksibel karena tahapannya membentuk suatu siklus sehingga kapanpun dapat dilakukan pengulangan dan perbaikan.

\section{METODE}

Penelitian ini merupakan penelitian eksploratif dengan pendekatan kualitatif. Teknik pengumpulan data berupa wawancara, analisis angket, dan observasi. Instrumen pengumpulan data penelitian ini berupa instrumen pedoman wawancara terhadap dosen pengampu matakuliah dan identifikasi permasalahan yang ada di lapangan berupa angket yang diberikan kepada 40 responden yang telah menempuh matakuliah anfisman berupa sumber belajar yang digunakan, karakteristik mahasiswa, kegiatan pembelajaran yang digunakan selama pembelajaran, dan kemampuan dalam memahami materi yang menjadi landasan dalam pengembangan produk dari sumber belajar. Pengambilan data dilakukan pada tanggal 12 Juli 2017 di Fakultas Ilmu Eksakta dan Olahraga Program Studi Pendidikan Biologi IKIP Budi Utomo Malang. Tahapan analisis kebutuhan merujuk pada tahap Analyze dalam model pengembangan ADDIE (Branch, 2009), yaitu (a) memvalidasi kesenjangan antara harapan dan fakta (validate the performance gap); (b) menentukan tujuan pegembangan (determine instructional goals); (c) mengonfirmasi target atau sasaran pengembangan (confirm the intended audience); (d) mengidentifikasi hal apa saja yang dibutuhkan dalam pengembangan (identify required resources); (e) menentukan sistem pengantar (determine potential delivery system); (f) menyusun rancangan pelaksanaan pengembangan (compose a project management plan).

\section{HASIL}

Hasil dari analisis sumber belajar dilakukan melalui wawancara terhadap dosen pengampu matakuliah Anfisman dan penyebaran angket terhadap mahasiswa yang telah menempuh matakuliah Anfisman, serta hasil dari observasi yang dianalisis secara deskriptif kualitatif berdasarkan tahapan analyze model pengembangan ADDIE dapat dijabarkan sebagai berikut.

\section{Memvalidasi kesenjangan antara harapan dan fakta (validate the performance gap)}

Kondisi ideal: tercapainya capaian pembelajaran pada matakuliah Anfisman dalam upaya memenuhi tuntutan kualifikasi kerangka Indonesia perlu didukung dengan adanya sumber belajar yang mendukung untuk melatih kemampuan mahasiswa dalam mengembangkan keterampilan abad 21 dan membantu selama proses pembelajaran.

Kondisi nyata: sumber belajar yang tersedia di IKIP Budi Utomo belum sepenuhnya membantu mahasiswa dalam belajar. Hal yang ditemukan terkait sumber belajar, meliputi (1) pesan atau konsep teoritis pada matakuliah anfisman khususnya materi system peredaran darah masih dianggap sulit dipahami oleh 62,5\% mahasiswa; (2) sumber belajar berupa manusia atau dalam hal ini merupakan dosen pengampu matakuliah anfisman memiliki riwayat pendidikan terakhir magister pendidikan, yang belum sesuai dengan bidangnya untuk membelajarkan materi anfisman pada mahasiswa S, (3) alat yang digunakan dalam proses pembelajaran berupa proyektor multimedia yang jumlahnya terbatas sehingga seringkali menggunakan papan tulis; (4) metode atau teknik yang digunakan selama proses belajar mengajar 43,8\% mahasiswa menyatakan presentasi dan diskusi kelompok, sedangkan yang lainnya menjawab ceramah, penugasan dan tanya jawab, akibatnya 43,4\% mahasiswa kurang dalam pemahaman materi dan kurang meningkatkan dalam pemecahan masalah; (5) lingkungan yang digunakan selama matakuliah Anfisman hanya terjadi di dalam kelas karena terbatasnya laboratorium, serta alat dan bahan praktikum; (6) bahan belajar yang digunakan berupa buku teks berisi teori dan latihan soal yang kurang merangsang mahasiswa dalam berpikir analitis menurut 43,7\% mahasiswa. Buku teks yang digunakan selama ini masih kurang memberdayakan keterampilan mahasiswa dalam proses pembelajaran, serta belum mengaitkan dengan kehidupan sehari-hari menurut $85 \%$ responden. 52,7\% responden menyatakan jarang memanfaatkan buku teks sehingga mahasiswa lebih sering menggunakan laman internet untuk mencari informasi dan referensi. 


\section{Menentukan Tujuan Pengembangan (determine instructional goals)}

Hasil identifikasi permasalahan yang ditemui di lapangan menunjukkan bahwa mahasiswa masih belum dapat belajar secara mandiri dan bergantung dari penjelasan dosen. Oleh sebab itu, dibutuhkan sebuah bahan ajar berupa sumber belajar yang dapat memfasilitasi mahasiswa dalam kegiatan ilmiah dan didukung dengan hasil penelitian laboratorium untuk mengeksplorasi wawasana mahasiswa agar dapat menghubungkan materi pembelajaran dengan kehidupan sehari-hari. Dengan demikian, pembelajaran menjadi aplikatif dan selalu mengikuti perkembangan IPTEK.

\section{Melakukan Konfirmasi Target atau Sasaran Pengembangan (confirm the intended auidience)}

Sasaran target dalam pengembangan ini adalah dapat mengembangkan sumber belajar untuk meningkatkan keterampilan abad 21 dan pemahaman mahasiswa selama proses pembelajaran Anfisman khusunya matakuliah sistem peredaran darah.

\section{Mengidentifikasi hal yang dibutuhkan dalam pengembangan (identify required resources)}

Hal yang dibutuhkan dalam pengembangan produk sebagai sumber belajar adalah buku wajib dan buku yang disarankan sebelumnya oleh dosen Anfisman sebagai sumber literatur, serta artikel atau literatur yang mendukung dalam penelitian untuk memberikan contoh kontekstual dan wawasan kepada mahasiswa. Hasil dari penelitian laboratorium akan menjadi contoh kontektekstual bagi mahasiswa sehingga dapat mengaitkan kehidupan sehari-hari dengan konsep yang dipelajarinya.

\section{Menentukan Sistem Pengantar (determine potential delivery system)}

Produk yang akan dikembangkan untuk mengatasi permasalahan yang dihadapi oleh mahasiswa IKIP Budi Utomo malang pada matakuliah Anfisman materi sistem peredaran darah adalah berupa kumpulan dari sumber belajar yang dapat digunakan secara mandiri oleh mahasiswa tanpa harus bimbingan dari dosen, dan disusun berdasarkan kebutuhan mahasiswa dan kompetensi akhir yang ingin dicapai sesuai dengan capaian pembelajaran.

\section{PEMBAHASAN}

Berdasarkan hasil penelitian, dibutuhkan adanya sumber belajar yang mampu mengatasi permasalahan yang ada untuk memenuhi capaian pembelajaran dan kompetensi yang dibutuhkan oleh calon guru. Hal ini dibuktikan berdasarkan hasil observasi, wawancara, serta analisis angket, bahwa terdapat adanya kesenjangan antara harapan dan fakta yang ditemukan dilapangan dari adanya sumber belajar sebagai daya dukung mahasiswa dalam belajar yang identifikasinya dilakukan berdasarkan tahapan Analyze ADDIE.

\section{Memvalidasi kesenjangan antara harapan dan fakta (validate the performance gap)}

Dunia pendidikan tengah dihadapkan dengan tantangan global yang menuntut individu memiliki keterampilan abad 21 agar dapat bersaing di era globalisasi. Peran pendidikan tinggi menjadi penting untuk membekali kemampuan mahasiswa terutama mahasiswa calon guru untuk mampu berperan aktif serta memiliki kompetensi sebagai calon pendidik dan mampu memberdayakan keterampilan abad 21, namun kondisi di lapangan kurang mendukung mahasiswa untuk memperoleh keterampilan tersebut, salah satu penyebabnya adalah karena rancangan kurikulum belum sepenuhnya mengacu pada KKNI disebabkan lemahnya sumber belajar yang tersedia. Macam sumber belajar menurut AECT dalam Daryanto (2010) terdiri dari pesan, manusia, bahan, alat, metode/teknik, dan lingkungan yang merupakan satu kesatuan dan saling ketergantungan.

Sumber belajar berupa pesan (message), merupakan informasi yang disampaikan dalam proses pembelajaran. Pada matakuliah anatomi fisiologi hewan, materi sistem peredaran darah merupakan materi yang dianggap sulit oleh $62,5 \%$ mahasiswa. Pesan atau konsep dalam materi tersebut belum diterima secara maksimal oleh mahasiswa dikarenakan materinya yang abstrak dan bersifat teoritis. Materi yang besifat teoritis akan lebih mudah dipahami oleh mahasiswa apabila dilakukan dengan pembelajaran yang kontekstual. Hal ini didukung oleh pernyataan (Johnson 2002; Muslich, 2007) pembelajaran yang kontekstual dapat mempermudahkan mahasiswa dalam memahami materi karena menghubungkan konsep yang dipelajari dengan konteks kehidupan sehari-hari, serta diorientasikan pada proses pengalaman secara langsung, sehingga dapat mendorong mahasiswa untuk menerapkannya dalam kehidupan sehari-hari. Penelitian (Samo dkk, 2018) menunjukkan adanya peningkatan kemampuan memecahkan masalah dengan pembelajaran yang kontekstual daripada pembelajaran yang konvensional. Alternatif pembelajaran yang didukung dengan hasil penelitian laboratorium diharapkan dapat menjadikan pembelajaran lebih kontekstual.

Sumber belajar selanjutnya adalah manusia (people). Manusia disini merupakan pendidik atau dosen pengampu matakuliah serta teman sabaya sebagai penyampai pesan. Apabila pesan berupa materi pembelajaran yang diterima mahasiswa bersifat teoritis dan abstrak, maka pendidik harus mampu menyampaikan pesan tersebut agar dapat diterima oleh mahasiswa, 
dengan cara mencari strategi pembelajaran yang tepat. Agar pengetahuan yang diterima mahasiswa tidak hanya sebatas hapalan. Suparmin (2012) mengungkapkan untuk dapat menghadapi dan mengajar mahasiswa dengan berbagai latar belakang, kepribadian yang berbeda, dan tingkat perkembangan beragam, maka seorang dosen perlu mengetahui keterampilan dasar pelajar, motivasi, latar belakang akademis, dan sosial ekonomi. Berdasarkan hasil observasi, sebagian besar mahasiswa di IKIP Budi Utomo berasal dari Indonesia bagian timur sehingga menjadi tantangan tersendiri bagi dosen agar dapat memilih strategi pembelajaran yang tepat. Apabila dosen memilih stategi pembelajaran yang bersifat teacher center, maka menjadi hambatan bagi mahasiswa untuk dapat menerima atau memahami konsep selama proses pembelajaran. Alasannya adalah adanya perbedaan bahasa, latar belakang akademis, dan dan kemampuan mahasiswa menerima pesan yang disampaikan oleh dosen berbeda-beda. Selain kemampuan pendidik dalam memilih strategi yang tepat, kualifikasi akademik dosen menurut Peraturan Pemerintah Republik Indonesia nomor 19 tahun 2017 juga penting bagi Dosen untuk mengajar sesuai dengan bidang keahliannya, yaitu matakuliah Anfisman.

Alat (device) merupakan sesuatu yang dapat digunakan untuk menyampaikan pesan sebagai sumber belajar (Daryanto, 2010). Berdasarkan hasil observasi, alat yang digunakan untuk menyampaikan materi/informasi dalam proses pembelajaran adalah proyektor multimedia yang jumlahnya terbatas, artinya tidak semua kelas tersedia proyektor multimedia. Keterbatasan alat untuk menyampaikan materi belajar menjadi salah satu kendala bagi pembelajaran terutama materi dalam anfisman, sehingga dalam proses pembelajarannya materi/informasi disampaikan lebih sering melalui papan tulis. Akibatnya mahasiswa menjadi kurang semangat untuk belajar, hal ini dapat dilihat pada saat observasi di dalam kelas mahasiswa lebih tertarik berbincang dengan teman sebayanya, dan tidak fokus dalam pembelajaran.

Metode yang sering digunakan pada matakuliah Anfisman menurut 43,8\% mahasiswa adalah presentasi dan diskusi kelompok, sedangkan yang lainnya menjawab ceramah, penugasan, dan tanya jawab. Dampak dari metode pembelajaran yang digunakan pada matakuliah ini menyebabkan 43,4\% mahasiswa kurang memahami materi, dan lainnya menjawab kurang meningkatkan berpikir kritis atau memecahkan masalah. Metode pembelajaran dengan diskusi informasi dan ceramah (teacher center) akan menyebabkan mahasiswa akan cenderung pasif dalam proses pembelajaran, konsep dalam matakuliah Anfisman yang didapat menjadi tidak maksimal, dan mahasiswa akan cenderung menghafal materi pelajaran untuk memenuhi tuntutan tujuan pembelajaran. Solusi dalam mengatasi permasalahan ini adalah dapat memberikan pengalaman belajar secara langsung kepada mahasiswa, sehingga mahasiswa dapat mengkonstruksi pengetahuannya sendiri melalui kegiatan ilmiah yang merupakan inti dari pembelajaran sains. Kegiatan ilmiah akan lebih efektif jika diterapkan dengan penerapan model pembelajaran inkuiri (Opara, 2011). Hal ini dikarenakan model pembelajaran inkuiri memberikan kesempatan mahasiswa melakukan penyelidikan (Yuliati, 2008) seperti yang dilakukan oleh ilmuan (Abdi, 2014) sehingga lebih banyak memberikan kesempatan kepada mahasiswa untuk mendapatkan konsep yang lebih dalam dan menjadi pemikir yang kritis (Vlassi \& Karaliota, 2013) dan (Ergül et al., 2011), menumbuhkan keterampilan proses sains dan bersikap ilmiah dalam mengkonstruk pengetahuan yang baru (Hussain \& Azeem, 2011) dan (Ergül et al., 2011). (Wilke \& Straits, 2006) menambahkan bahwasanya pembelajaran yang mengandung banyak konsep akan lebih efetif dilakukan dengan proses penyelidikan dalam pembelajaran inkuiri dan akan memberikan keterampilan proses sains pada siswa. Keterampilan proses sains perlu dikembangkan karena dapat menyederhanakan pembelajaran sains, mengaktifkan peran mahasiswa, mengembangkan rasa ingin tahu dan tanggungjawab dalam suatu pembelajaran, serta mengajarkan metode penelitian kepada mahasiswa (Karamustafaoğlu, 2011). Keterampilan proses sains berhubungan dengan salah satu capaian pembelajaran yang harus dicapai oleh mahasiswa yaitu menguasai konsep aplikasi Biologi. Penguasaan konsep menjadi lebih bermakna apabila mahasiswa menemukan sendiri konsep yang dipelajarinya melalui proses belajar yang didukung dengan sumber belajar yang ada di sekitarnya.

Sumber belajar selanjutnya adalah lingkungan (setting). Lingkungan merupakan situasi dimana pesan/informasi dalam proses pembelajaran disampaikan (Daryanto, 2010). Lingkungan yang selama ini digunakan dalam matakuliah Anfisman adalah di dalam kelas. Pembelajaran sains, seperti anfisman idealnya dilakukan dengan praktikum di dalam laboratorium karena merupakan materi yang abstrak, agar mahasiswa mendapatkan pengalaman belajarnya sehingga mampu membangun konsepnya sendiri. Faktanya praktikum anfisman jarang diterapkan, alasannya spesifik seperti kurangnya laboratorium dan kurangnya fasilitas alat laboratorium. Menurut (Gabel, 1993) kendala dari kurangnya implementasi kegiatan di laboratorium adalah kurangnya peralatan dan bahan lab serta kurangnya keterampilan pendidik dalam mengelola kegiatan lab. Sementara itu, menurut (Anggreini, 2001) banyaknya pendidik yang enggan melakukan kegiatan praktikum di dalam laboratorium karena menghabiskan banyak waktu dan energi. Kurangnya praktikum di dalam laboratoium berdampak pada rendahnya keterampilan proses sains mahasiswa. Solusi untuk mengatasi terbatasnya peralatan dan bahan lab menurut (Prajoko, Amin, Rohman, \& Gipayana, 2017) adalah dengan mendaur ulang bahan/peralatan yang berasal dari limbah anorganik, misalnya dengan memanfaatkan botol minuman dan sedotan sebagai pengganti alat respirometer. Hasil analisis data penelitian Prajoko tersebut dengan memanfaatkan limbah anorganik pada praktikum sains secara signifikan memengaruhi keterampilan proses peserta didik. Artinya, untuk melakukan kegiatan ilmiah atau praktikum tidak harus menggunakan alat-alat yang mahal, bagaimana kreativitas pendidik dapat menciptakan sumber belajar yang bisa meng-cover pembelajaran menjadi maksimal. 
Bahan belajar merupakan salah satu dari sumber belajar yang digunakan untuk matakuliah Anfisman. Bahan belajar yang digunakan selama ini menurut $43,7 \%$ responden menyatakan buku teks. Buku teks yang digunakan selama ini masih belum mengangkat fenomena sehari-hari atau belum kontekstual menurut $85 \%$ mahasiswa, isinya berupa teori dan latihan soal, sehingga 52,7\% mahasiswa kerap kali menggunakan laman internet yang masih belum jelas sumbernya. Sanjaya (2011) menyatakan keberhasilan dari suatu pembelajaran dapat direalisasikan melalui penyampaian materi melalui bahan ajar. Bahan ajar yang dapat digunakan dalam pembelajaran dapat berupa buku teks, modul, lembar keja siswa (Amri, 2010). Berdasarkan observasi mahasiswa juga belum dapat belajar secara mandiri karena masih bergantung dari penjelasan dosen. Sesuai dengan permasalahan yang dihadapi oleh mahasiswa di IKIP Budi Utomo Malang agar dapat menguasai materi dengan menerapkan keterampilan proses secara mandiri, maka bahan ajar yang cocok digunakan adalah modul. Pemilihan modul sebagi sumber belajar juga memperhatikan dari kondisi sarana dan prasarana yang ada di IKIP Budi Utomo yang kurang menunjang apabila menggunakan media elektronik. Anwar (2010) mengungkapkan modul pembelajaran adalah bahan ajar yang disusun secara sistematis dan dapat digunakan secara mandiri untuk mencapai kompetensi yang diharapkan. Kelebihan dari modul dalam pembelajaran adalah fokus pada kemampuan individual mahasiswa serta adanya kontrol terhadap hasil belajar melalui penggunaan standar kompetensi yang dicapai oleh mahasiswa (Mulyasa, 2006).

\section{Menentukan Tujuan Pengembangan (determine instructional goals)}

Sumber belajar merupakan salah satu komponen dalam sistem pengajaran yang saling berhubungan dan saling ketergantungan antar komponen lainnya (Daryanto, 2010). Berdasarkan hasil identifikasi kelemahan sumber belajar yang telah dilakukan untuk membantu mahasiswa dalam sistem pembelajaran, maka dibutuhkan suatu bahan ajar berupa modul yang dapat digunakan secara mandiri yang memuat pembelajaran yang kontekstual serta memfasilitasi kegiatan praktikum mahasiswa, agar mahasiswa dapat memperoleh pengalaman belajarnya secara langsung, dan dapat menemukan konsepnya secara mandiri sehingga mahasiswa tidak hanya belajar teori dan dapat mengaitkan konsep yang didapat dengan kehidupan sehari-hari.

\section{Melakukan Konfirmasi Sasaran Pengembangan (confirm the intended auidience)}

Produk yang akan dikembangkan berdasarkan hasil analisis kebutuhan mahasiswa berupa Modul Anfisman berbasis inkuiri terbimbing berdasarkan hasil penelitian laboratorium. Model pembelajaran inkuiri yang terintegrasi di dalam modul akan berisi kegiatan ilmiah dan memfasilitasi kegiatan praktikum mahasiswa. Kegiatan ilmiah seperti dilakukannya praktikum akan memabantu mahasiswa dalam mengembangkan keterampilan proses sains. Modul yang memuat hasil penelitian laboratorium untuk menampilkan pembelajaran yang kontekstual, serta memberi wawasan yang luas kepada mahasiswa. Contoh kontekstual dalam pengembangan modul berupa penyakit yang banyak diderita oleh masyarakat, yaitu diabetes mellitus.

Menurut International Diabetes Federation (IDF) pada tahun 2017 memperkirakan sekitar 87—91\% orang di dunia menderita Diabetes Mellitus Tipe 2 (DMT2). DMT2 menurut American Diabetes Association (ADA) tahun 2010 merupakan penyakit metabolik yang ditandai dengan naiknya gula darah karena tidak dapat memproduksi cukup insulin akibat terjadinya resistensi insulin. Harapan dari pengembangan produk selain mahasiswa dapat mengaitkan penyakit dengan materi sistem peredaran darah, dapat melatih mahasiswa mengembangkan keterampilan proses sains dan mengembangkan kognitif mahaiswa yang didukung dengan pernyataan (Furqan, Yusrizal, \& Saminan, 2016). (Choerunnisa, Wardani, \& Sumarti, 2017) dalam penelitiannya juga menambahkan pendekatan kontekstual dengan inkuiri dapat meningkatkan literasi sains peserta didik.

\section{Mengidentifikasi hal yang dibutuhkan dalam pengembangan (identify required resources)}

Hal yang dibutuhkan dalam kebutuhan sumber belajar di IKIP Budi Utomo berupa pengembangan modul. Modul yang dikembangkan dapat berisikan konten yang harus dipelajari oleh mahasiswa, artikel yang mendukung pengembangan modul sebagai rujukan dalam menyusun hasil penelitian, serta hasil penelitian laboratorium sebagai contoh kontekstual, salah satunya yang dapat dikontekstualkan dalam materi Anatomi Fisiologi Manusia, yaitu penyakit diabetes mellitus.

\section{Menentukan Sistem Pengantar (determine potential delivery system)}

Produk yang akan dikembangkan untuk mengatasi permasalahan yang dihadapi oleh mahasiswa IKIP Budi Utomo Malang pada matakuliah Anfisman materi sistem peredaran darah adalah modul berbasis inkuiri berdasarkan hasil penelitian laboratorium. Mahasiswa akan melakukan kegiatan pembelajaran berdasarkan tahapan model pembelajaran inkuiri dengan pendekatan kontekstual yang dihubungkan dengan kehidupan nyata yaitu penyakit DMT2. Bahan ajar berupa modul dipilih karena modul dapat digunakan secara mandiri tanpa harus bimbingan dari dosen, modul akan disusun berdasarkan kebutuhan mahasiswa dan kompetensi akhir yang ingin dicapai sesuai dengan capaian pembelajaran. Modul tersebut ditulis dengan gaya penulisan yang komunikatif sehingga dapat memudahkan mahasiswa dalam belajar. 


\section{SIMPULAN}

Berdasarkan hasil analisis kebutuhan sumber belajar peserta didik di IKIP Budi Utomo Malang, maka diperlukan sumber belajar yang tepat dengan saling menghubungkan antar sumber belajar, yaitu berupa bahan ajar modul berbasis inkuiri yang terintegrasi dengan penelitian laboratorium. Modul berbasis inkuiri untuk memberikan pengalaman belajar secara langsung karena peserta didik akan melakukan investigasi untuk membuktikan suatu hipotesis sehingga dibutuhkan lingkungan belajar di laboratorium. Dosen sebagai sumber belajar berperan dalam membimbing jalannya proses pembelajaran karena metode yang digunakan adalah inkuiri terbimbing sehingga membutuhkan bimbingan pendidik dalam menjalankan langkahlangkah inkuiri. Pembelajaran yang kontekstual berdasarkan hasil penelitian laboratorium yang terintegrasi di dalam modul akan membuka wawasan peserta didik dan menampilkan pembelajaran yang kontekstual sehingga peserta didik dapat mengaitkan konsep yang dipelajarinya dengan contoh kehidupan sehari-hari. Tujuan penelitian ini adalah untuk mengetahui sumber belajar pada matakuliah Anatomi Fisiologi Manusia. Untuk mengetahui sumber belajar matakuliah Anatomi Fisiologi Manusia perlu dilakukan analisis untuk matakuliah lain sehingga dapat memberikan kontribusi solusi dalam memenuhi ketercapaian pembelajaran sesuai dengan kompetensi mahasiswa.

\section{DAFTAR RUJUKAN}

Abdi, A. (2014). The Effect of Inquiry-Based Learning Method on Students' Academic Achievement in Science Course. Universal Journal of Educational Research, 2(1), 37-41. https://doi.org/10.13189/ujer.2014.020104

Branch, R. M. (2009). Instructional Design: The ADDIE Approach. New York: Springer.

Choerunnisa, R., Wardani, S., \& Sumarti, S. S. (2017). Keefektifan Pendekatan Contextual Teaching Learning dengan Model Pembelajaran Inkuiri terhadap Literasi Sains. Jurnal Inovasi Pendidikan Kimia, 11(2), 1945-1956.

Daryanto. (2010). Belajar dan Mengajar. Bandung: Yrama Widya.

Ergül, R., Şımşeklı, Y., Çaliş, S., Özdılek, Z., Göçmençelebı, Ş., \& Şanli, M. (2011). The Effects of Inquiry-Based Science Teaching on Elementary School Students' Science Process Skills and Science Attitudes. Bulgarian Journal of Science and Education Policy.

Johnson, Elaine B. (2002). Contextual Teaching \& Learning: What It Is and Why Its Here to Stay. California: Corwin Press, Inc

Furqan, H., Yusrizal., \& Saminan. (2016). Pengembangan Modul Praktikum Berbasis Inkuiri untuk Meningkatkan Keterampilan Proses Sains dan Hasil Belajar Siswa Kelas X di SMA Negeri 1 Bukit Bener Meriah. Jurnal Pendidikan Sains Indonesia, 4(2), 124-129. https://doi.org/10.1080/01445340.2016.1210986

Hussain, A., \& Azeem, M. (2011). Physics Teaching Methods: Scientific Inquiry VS Traditional Lecture. International Journal of Humanities and Social Science, 1(19), 269-276.

Karamustafaoğlu, S. (2011). Improving the Science Process Skills Ability of Science Student Teachers Using I Diagrams. Eurasian Journal of Physics and Chemistry Education, 3(1), 26-38.

Muslich, M. (2007). KTSP Pembelajaran Berbasis Kompetensi dan Kontekstual. Jakarta: Penerbit Bumi Aksara.

Opara, J. A. (2011). Inquiry Method and Student Academic Achievement in Biology: Lessons and Policy Implications. American-Eurasian Journal of Scientific Research, 6(1), 26-38.

Prajoko, S., Amin, M., Rohman, F., \& Gipayana, M. (2017). The Usage of Recycle Materials for Science Practicum: Is There Any Effect on Science Process Skills? International Journal of Evaluation and Research in Education (IJERE). https://doi.org/10.11591/ijere.v6i1.6340

Purwanto, N. (2003). Psikologi Pendidikan. Jakarta: Remaja Rosdakarya.

Suparmin, M. (2012). Makna Psikologi Perkembangan Peserta Didik. Jurnal Ilmiah SPIRIT, 10(2), 28-68.

Vlassi, M., \& Karaliota, A. (2013). The Comparison between Guided Inquiry and Traditional Teaching Method. A Case Study for the Teaching of the Structure of Matter to $8^{\text {th }}$ Grade Greek Students. Procedia - Social and Behavioral Sciences. https://doi.org/10.1016/j.sbspro.2013.09.226

Wilke, R. R., \& Straits, W. J. (2006). Practical Advice for Teaching Inquiry-Based Science Process Skills in the Biological Sciences. The American Biology Teacher, 67(9), 534-540. https://doi.org/10.1662/00027685(2005)067[0534:paftis]2.0.co;2 